\title{
Government Activities on Facebook: A Content Analysis of Selected Government Ministries' Facebook pages in Bangladesh
}

\author{
Shaharima Parvin \\ Assistant Librarian \\ East West University, Bangladesh \\ Email: shaharimaparvin@gmail.com
}

\begin{abstract}
:
Social media sites are the world's biggest information dissemination platform and today's we cannot imagine to share our any information without these sites. It has been a leading manifestation in our lives in the past several years. Various profit and non-profit organization in Bangladesh are using Facebook to promote their services and highlight their roles to community. Now, government different ministries have accepted the opportunities of using Facebook to deliver better services as well as engage with citizens.
\end{abstract}

The present study intends to examine the government ministries' Facebook pages in Bangladesh to explore what types of information are disseminated on their Facebook pages, how effective these pages are in reaching out to citizens as well as engagement. Qualitative content analysis of four selected government ministries' Facebook pages has conducted to fulfill the research aims. Content analysis allows describing the material only on selected aspects, on the other hand method is highly flexible as coding frame is always adjustable to the material. The researcher has selected four ministries Facebook pages and among these pages, two are verified and another two pages are not verified. The researcher has developed the categories and codes according to fulfill the research aims. Data collection has started by identifying the usage Facebook of each ministries and found that each ministries has incorporated Facebook logo in their website. After that, the information provided on 'about' section was put down, the number of likes/followers, the existence of profile picture, cover photo, and other applications has been identified. The data collection for content analyses was conducted in six months posting messages between October 2017 to March 2018 were recorded as well as organized and analyzed by using Microsoft Office Excel program.

Keywords: Facebook, Information Dissemination, Content Analysis, Government Institution, Civic engagement, Bangladesh 


\section{Prologue:}

Social media sites are the world's biggest information dissemination platform and today's we cannot imagine to share our any information without these sites. It has been a leading manifestation in our lives in the past several years. These sites have transformed our communication media from conventional forms to participatory forms and now we can express and share our opinions using these tools. Kaplan and Haenlein (2010) define social media as "a group of Internet-based applications that build on the ideological and technological foundations of Web 2.0, and that allow the creation and exchange of User Generated Content." (p. 61). "Social media are internet-based applications designed to facilitate social interaction and for using, developing and diffusing information through society" (Kavanaugh et al., 2012). Therefore, the emergence of social media is acting as vital role to accelerate social communication between indigenous communities and global communities. As citizens have been empowered by the use of social media, governments have found themselves obliged to listen and interact with them to a higher degree (Warren et al., 2014). Openness, accountability, and honesty delineate government transparency and it is very imperative as well as government's commitment to share information with citizens in time. Government's use of social media leads not only to establish open government improving transparency, participation, and collaborations with public but also "designs public policies, innovation in public services delivery in more iterative, collaborative and responsive ways" (Mickoleit, 2014). Governments around the globe have started utilizing various social media, such as blogs, Wikis, social networking, and microblogs to disclose the policy process subsuming bidding and contracting to the public, to facilitate citizens' monitoring of functionaries' activities, to build channels for functionaries to disseminate information to citizens, and to allow citizens to monitor their interactions with functionaries (Bertot et al.,2012).

The total population of Bangladesh is 165.5 million and the internet penetration rate is 49 percentages whereas active social media users' rate is 18 percentages (We Are Social, 2018). According to Alexa, the ranking of top websites based on the number of pages viewed on each site per visit, Facebook has placed on third position after Google and YouTube in Bangladesh. Various profit and non-profit organization in Bangladesh are using Facebook to promote their services and highlight their roles to community. Azad et al. (2017) found that government organizations used Facebook page and groups with different goals and objectives such as "to communicate with the public in a new way; develop internal communication and encourage service innovation, knowledge sharing and problem solution". The present study intends to examine the government ministries' Facebook pages in Bangladesh to explore what types of information are disseminated on their Facebook pages and how effective these pages are in reaching out to citizens as well as engagement.

\section{Literature Review:}

The study concentrates primarily on two research areas-information dissemination by government using social media and the significance of using social media for citizen engagement. 
The main characteristics of social media are participation, openness, conversation, engagement and connectedness (Eltantawy and Wiest, 2011; Kim et al., 2014; Zheng and Zheng 2014). In addition, Freeman (2016, p. 197) stated that digital technologies are redefining understandings and practices associated with democratic participation. Openness, accountability, and honesty delineate government transparency and it is very imperative as well as government's commitment to share information with citizens in time. Government's use of social media leads to establish open government improving transparency, participation, and collaborations with public. However, government institutions have policy about what types of information to be shared and the manner of sharing in order to maintain government transparency. When, social media has achieved popularity among people then government institutions did not consider using social media as they deemed that social media is demonstrating for recreational purpose. But now most governments have changed their opinions and they are using social media as they are not a place for discussion rather, they have become a vehicle for the institution of collective action (Mickoleit, 2014).

O'Really (2010) describes that web 2.0 technologies assist government leaders to be elected as well as to get a better job and this movement is called Government Web 2.0. "A more open, social, communication, interactive and user-centered version of e-government" (Meijet et al., 2012, p. 23) is described as Government 2.0. As, Web 2.0 is recognized as the advent of social media so government has huge possibilities to employ this platform. Bertot et al. (2010) points out the four major possibilities of using social media: "collaboration, participation, empowerment, and time" (p. 239). In addition, Criado el al. (2013) highlight that "Social media in government is becoming one of the major trends in electronic government research, and practice worldwide.

Many researchers agree that using social media by government for information dissemination and citizen engagement has various benefits for both government and citizen and these benefits are effective to transform the e-government movement to we-government" (Linders, 2012, p. 464). Government can use social media to design public policies, innovation in public services delivery in more iterative, collaborative and responsive ways. (Mickoleit, 2014).

Social media can assist government to improve communication, both regular and emergency e.g., earthquake, flash mob gathers, protests, traffic for the public safety and improve the quality of daily life. Besides, by using social media government can manage information and facilitate interaction to achieve board public participation than is possible through normal channels (Kavanaugh et al., 2012). The citizens of USA get information about what's going on not only in their community but also national and global current events through social media (Kavanaugh et al., 2012). "Social media offers an especially compelling environment for engaging with news, information and discussion about political issues" (Duggan and Smith, 2016).

However, Mickoleit (2014) specified that government institutions are not clear about the aim of using social media therefore, they felt uncertainty about the proper demonstration of social media and the implications for strategic objectives as well as daily activities in social media. The government can engage not only with the citizens but also with international community. Roseland and Mark (2010) consider social media as a powerful tool for sustainable community 
development. Nevertheless, government needs to professionalize their behavior in social media (Margel, 2012) and to prepare themselves to overcome the challenges of social media subsuming privacy, data security issue, quality of information, public perception and so on. The perceptions of using social media by government can be very different from country to country or within countries. Government institutions, political personalities accepted social media slowly. Roengtam et al. (2017) investigated the impact of the use of social media on the organizational form and function in selected local governments of Indonesia, Thailand and the Philippines and advocate with the previous research that "social media use in local government is only for information dissemination and for receiving feedback or inputs from the citizens" (p.362). Bonsón, Royo and Ratkai (2017) stated that Western European local government use Facebook for stakeholder's engagement as well as suggest that local governments need to choose different media and content types depend on the institutional context.

\section{Usage of social networking sites by government ministries:}

The 26 OECD member countries out of 34 operate a Twitter account whereas 21 countries maintain a Facebook page and many ministries and specialized agencies operate on social media at regional and local levels of government. Facebook and Twitter are the most popular social media platform around the world. Khan et al. (2014) highlight that in South Korea, Twitter has been working as a tool for networking among government institutions whereas in the UK, a significant number of local governments using Facebook and Twitter (Ellison and Hardey, 2014) and issued several guidelines for using social media (Srivastava, 2012).

In Australia, the councils distinguished that "social media offer new means for communicating with citizens as well as councils using social media predominantly focus on information dissemination to further distribute media releases and promote local events, and recognized the value added by this practice (Freeman, 2016 p. 209). In the United States of America, governments agencies are extensively using the social media to interact and inform its citizenry. Facebook and Twitter boosted grassroots presidential campaign. On the other hand, Facebook and Orkut, together cater to about 90 per cent of the users in the social media space in India and Government has started to use Facebook as well as Twitter for engaging in political and policy discourses; posting all information regarding important bills, legislations, prime minister (PM statements), press releases, official visits (Srivastava, 2012).

\section{Social Networking Sites uses by government's institutions in Bangladesh:}

Bangladesh is trying to develop its socio-economic condition by giving emphasis on education, agriculture and industrialization. Bangladesh has been gaining immense success in every branch of the government especially making digital Bangladesh. Now, Bangladesh has been experiencing a rapid rise in the number of mobile Internet users. The total number of Mobile Phone subscriptions has reached 150.283 one hundred fifty point two hundred eighty three million at the end of March, 2018 and the total number of Internet Subscribers has reached 84.545 eighty four point five hundred forty five million at the end of March, 2018

whereas subscribers has reached thirty one point one four zero million at the end of February, 
2012 (BTRC 2018). Therefore, we can distinguish the upliftment of internet connectivity in Bangladesh.

The citizens are directly involved with the development of a country. Bangladesh is not its exception. The present development and success of Bangladesh is the result of combined efforts of the government and public. The interaction and engagement of public with the government can be increased by opening the window of government information to public. This will surely affect the efficiency of the government, ensure transparency and as well as will engage citizen in a true manner for nation-building. Government can't do anything unless the general public actively participate in the development activities whether directly and indirectly. In this regard, social media can play a great role to engage people and can seek their opinion, suggestions, constructive criticism, and fresh ideas in various development projects.

Azad et al. (2017) found in their research that more than 800 government organizations have presence in social media with their official Facebook page/group, and a few organizations have blogs and YouTube channels. They also described that Facebook is the most popular social media which can be used to draw government attention for solving social problems, creating awareness and motivation people.

Government different ministries have accepted the opportunities of using Facebook to deliver better services as well as engage with citizens. Facebook is one of the foremost social networking sites in Bangladesh. It has become an increasingly familiar sites for many government ministries to provide their services through an easy and cost effective way.

The above review of literature indicates that there are numbers of research have been conducted on the potential benefits of using Facebook by government but still there is an acute gap of literature on which types of information disseminating by ministries Facebook pages as well as the aims and practices of using Facebook page by government's institutions in Bangladesh. Thus, this study is the first attempt to identify the scenario.

Objectives of this study: The present study intends to

- Examine the government ministries' Facebook pages in Bangladesh to explore what types of information are disseminated on their Facebook pages

- How effective these pages are in reaching out to citizens as well as engagement

\section{Samples and Methods of the Study:}

The Cabinet of Bangladesh is the chief executive body of the People's Republic of Bangladesh. The Cabinet is the collective decision-making body of the entire government under the Office of the Prime Minister, composed of the Prime Minister and some 33 Cabinet Ministers, 18 State Ministers and 2 Deputy Ministers ("Cabinet of Bangladesh", 2018) . 
There are four ministries Facebook pages have been selected to fulfill the research aims subsuming:

1. Ministry of Power, Energy \& Mineral Resources, Bangladesh

2. Information and Communication Technology Division, Ministry of Posts Telecommunications and Information Technology

3. Ministry of Road Transport and Highways Division

4. Ministry of Civil Aviation and Tourism

As, the purpose of the research was to examine the current situation of government ministries using Facebook page to map what types of information are disseminated on their Facebook pages, and how effective these pages are in reaching out to citizens as well as engagement. To fulfil the purpose, the qualitative content analysis is used to collect and analyze data from government ministries' Facebook pages. Qualitative content analysis of four selected government ministries' Facebook pages has conducted to fulfill the research aims because it is the most effective way to map present condition of selected government ministries' Facebook pages. Besides, content analysis allows describing the material only on selected aspects, on the other hand method is highly flexible as coding frame is always adjustable to the material (Schreier, 2012).

The most important element of content analysis method is a categorization scheme. There are some standard category schemes, but for every study the researcher develops his own concrete content classification system, categories and codes (Weare \& Lin, 2013).

Among the selected four ministries Facebook pages, two are verified and another two pages are not verified. The researcher has developed the categories and codes according to fulfill the research aims. Data collection has started by identifying the usage Facebook of each ministries and found that each ministry has incorporated Facebook logo in their website. After that, the information provided on 'about' section was put down, the number of likes/followers, the existence of profile picture, cover photo, and other applications has been identified. The data collection for content analyses was conducted in six months posting messages between October 2017 and March 2018 were recorded. The collected material consists of textual data and media (photographs, videos).

Second part of analysis consisted of defining the number and content of wall posts

created by ministries. The researcher has identified the seven categories of wall posts. Which are:

1. Information about existing services

2. Promote new services

3. Awareness of citizen rights and responsibilities

4. Citizen engagement with government services

5. Government Officials

6. External links shared by Ministries Facebook Pages

7. Others (posts related to national and international events or other activities which are not related to government services.) 
About each wall post the topic of content was determined, also the amount of comments, likes and shares were identified. The Facebook posts that were in native language were translated into English Google Translate. Finally, the data collected with content analysis was organized and analyzed in program Microsoft Office Excel program.

\section{Results and discussion:}

Use of Facebook page by different ministries: The selected four ministries' Facebook pages have been trying to promote their pages among community. The table 1 shows the name of Ministries and Number of Followers/Likes:

\begin{tabular}{|l|l|}
\hline Name of Ministries & $\begin{array}{l}\text { Number } \\
\text { Followers/Likes }\end{array}$ \\
\hline $\begin{array}{l}\text { Ministry of Power, Energy \& Mineral Resources, } \\
\text { Bangladesh }\end{array}$ & $\begin{array}{l}1,095,770 \text { likes and } \\
1,097,338 \text { followers }\end{array}$ \\
\hline $\begin{array}{l}\text { Information and Communication Technology Division, } \\
\text { Ministry of Posts Telecommunications and Information } \\
\text { Technology }\end{array}$ & $\begin{array}{l}3,33,605 \text { likes and 3,40,238 } \\
\text { followers }\end{array}$ \\
\hline $\begin{array}{l}\text { Ministry of Road Transport and Highways Division } \\
\text { Ministry of Civil Aviation and Tourism }\end{array}$ & $\begin{array}{l}3,102 \text { likes and 3,118 } \\
\text { followers }\end{array}$ \\
\hline
\end{tabular}

Activeness of Government Ministries Facebook Page: The number of wall post during the data collection period has been collected to measure the activeness of the selected Facebook pages. The researcher has identified the seven categories of wall posts. The following tables show the name of ministries Facebook pages and the amount of only selected posts per month for the measure of activeness by administrating Facebook page:

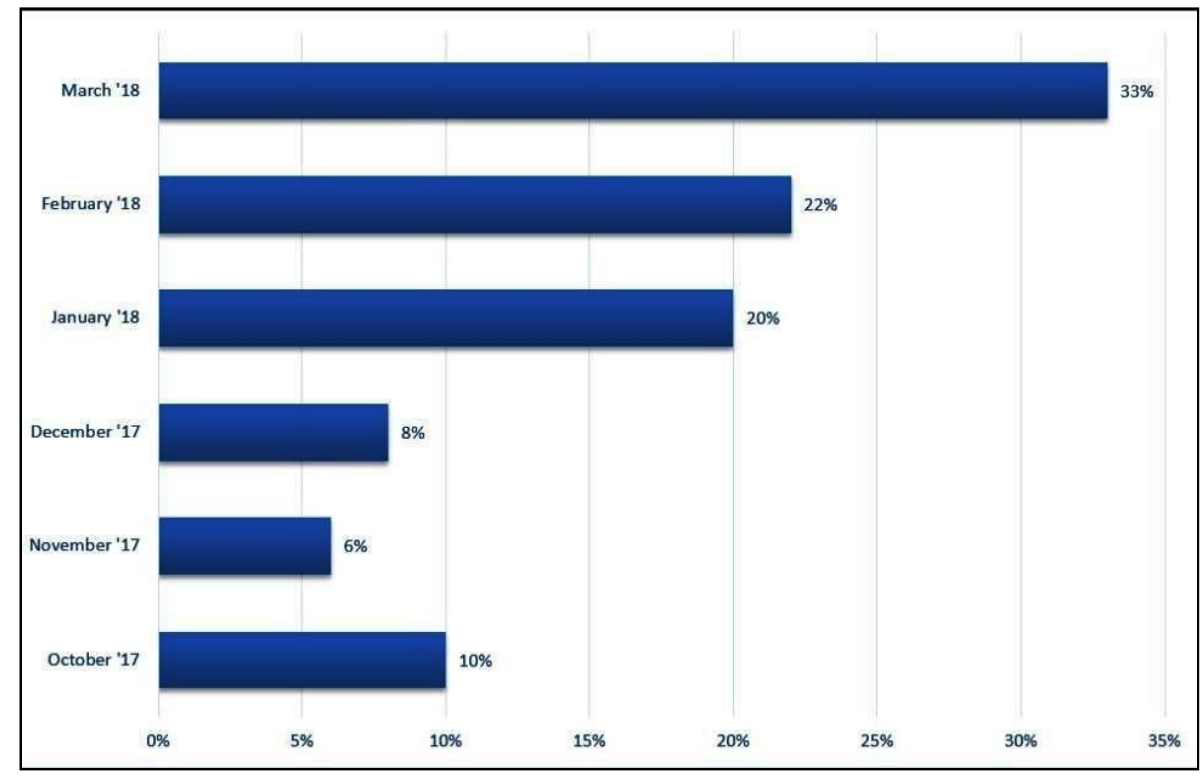

Figure: 1 Ministry of Power, Energy \& Mineral Resources, Bangladesh 


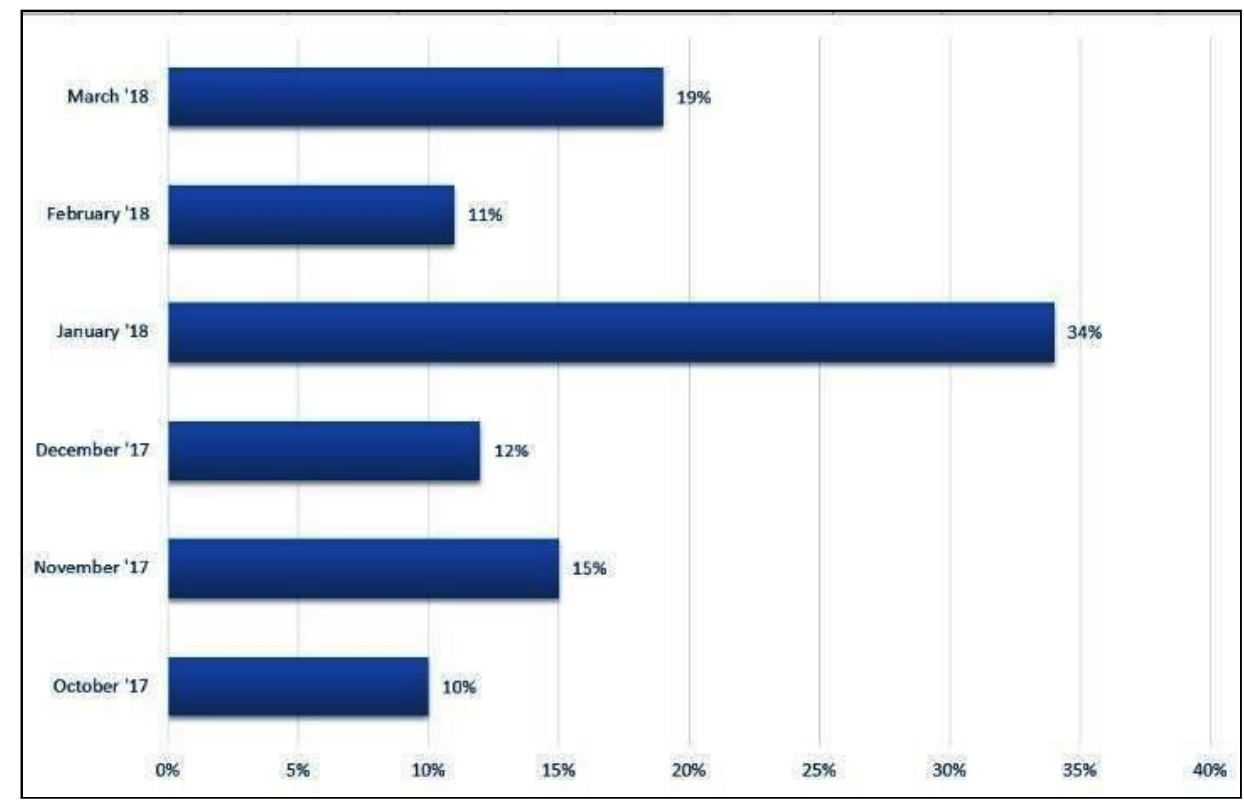

Figure: 2 Information and Communication Technology Division, Ministry of Posts Telecommunications and Information Technology

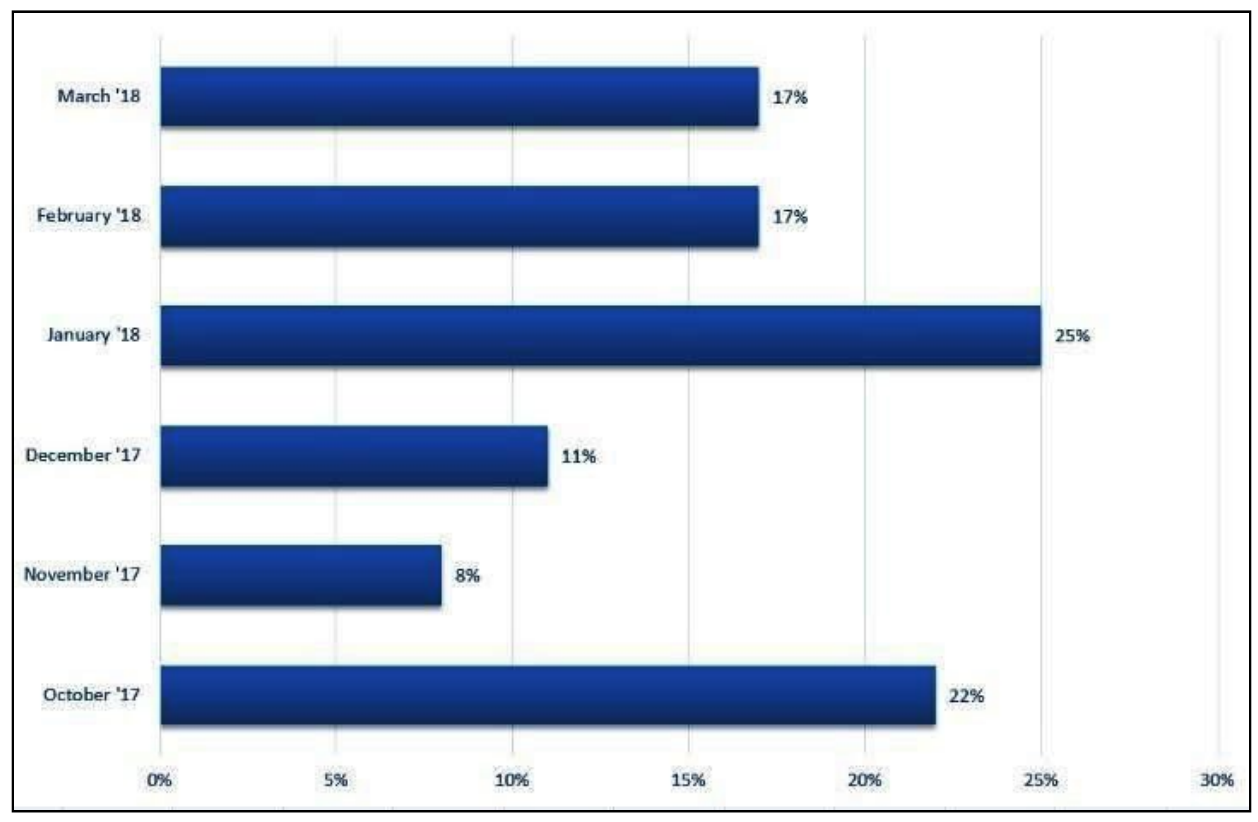

Figure: 3 Road Transport and Highways Division 


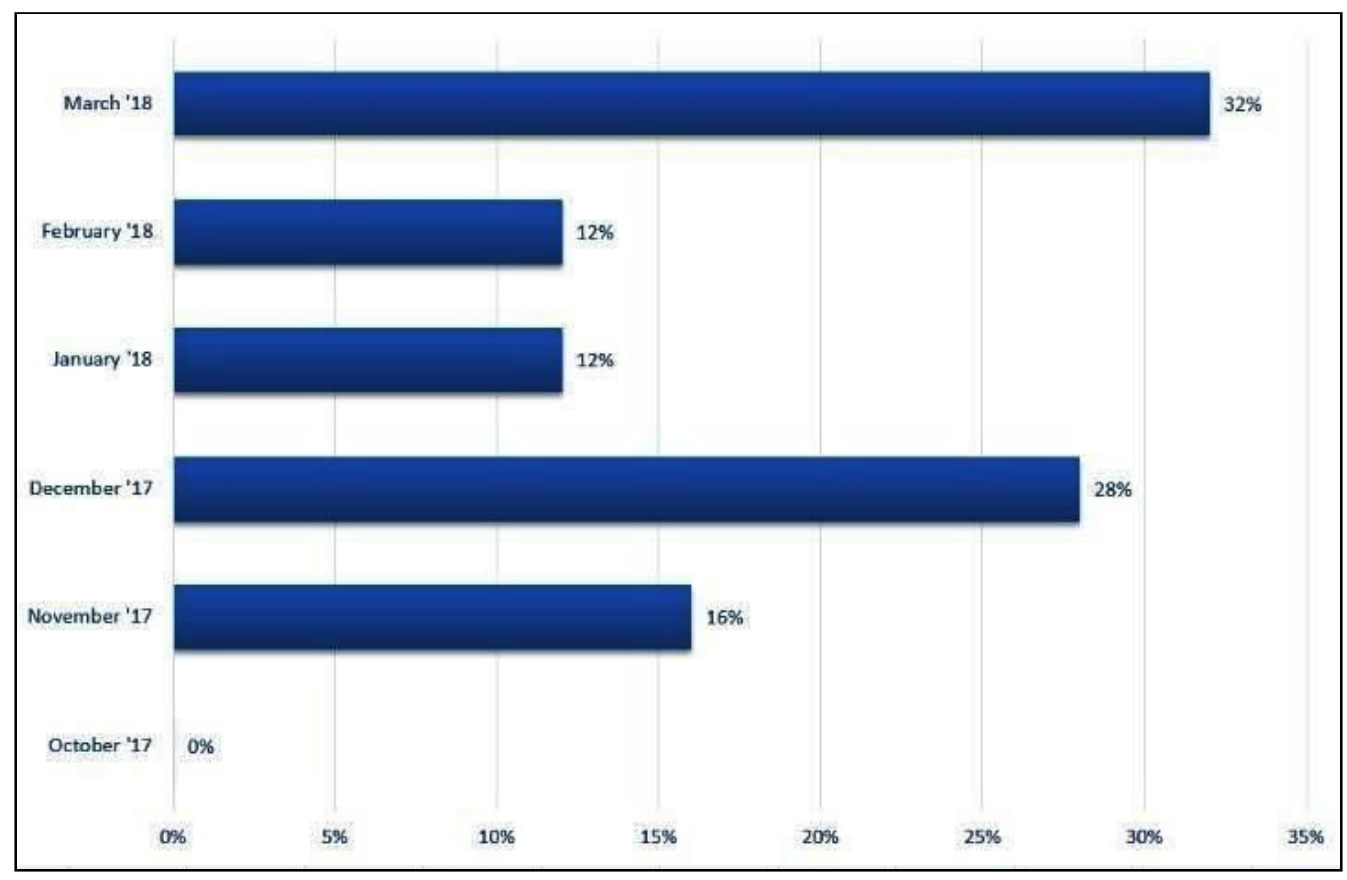

Figure: 4 Ministry of Civil Aviation and Tourism

\section{Content of wall posts of all ministries Facebook pages:}

The total wall posts of these categories are 411. The following tables reveal the percentages of these wall posts. Figure 5 shows that Ministry of Power, Energy \& Mineral Resources, Bangladesh Facebook Page picked more posts categories on promote of new services $(24.69 \%)$ and information about existing service (20.99\%).

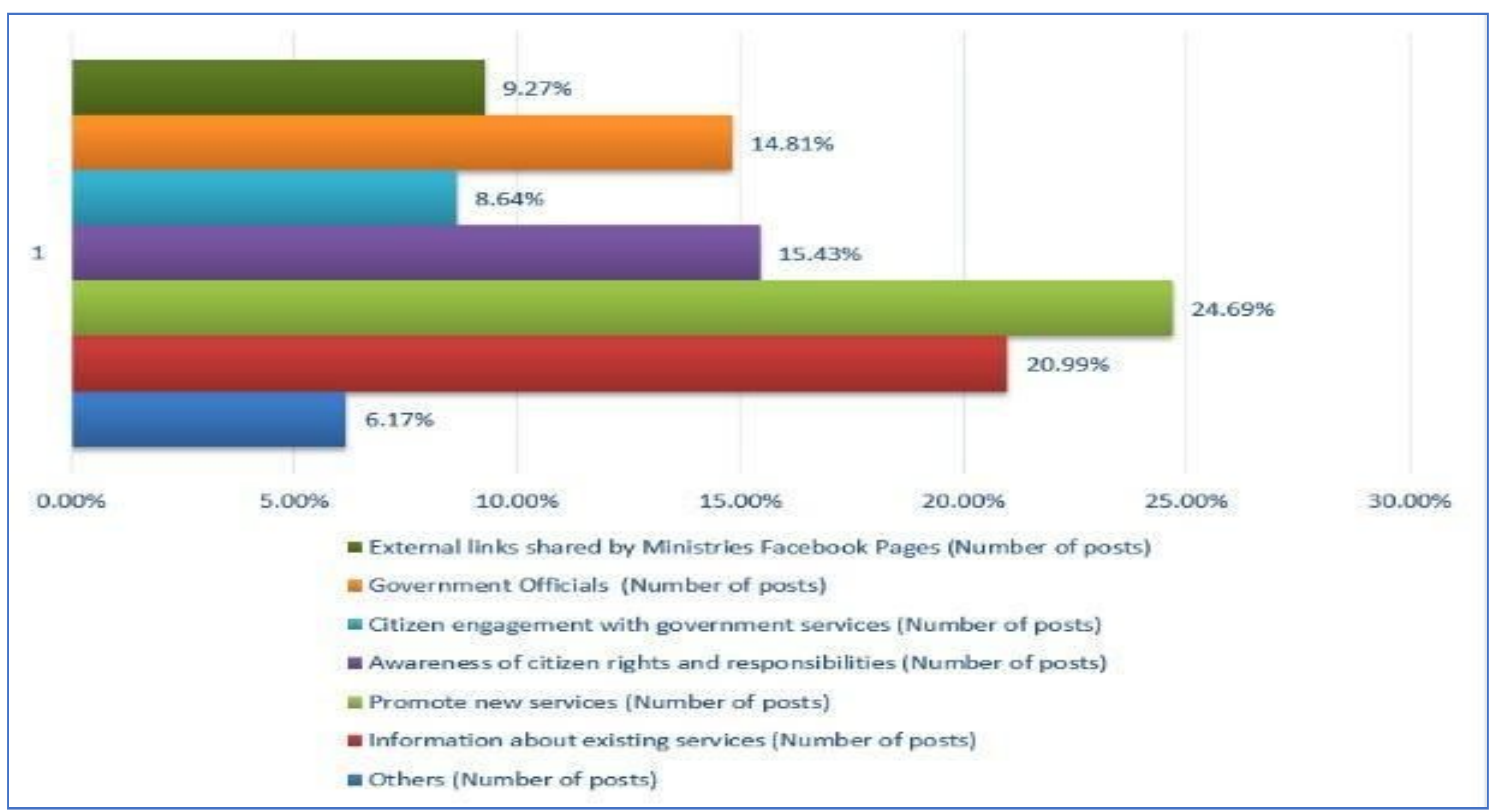

Figure: 5 Content of wall posts of Ministry of Power, Energy \& Mineral Resources, Bangladesh Facebook Page (In Percentages) 
Figure 6 highlights that Information and Communication Technology Division, Ministry of Posts Telecommunications and Information Technology page emphasized on categories such as external links shared by Ministries Facebook Pages (36.70\%) and citizen engagement with government services $(19.68 \%)$.

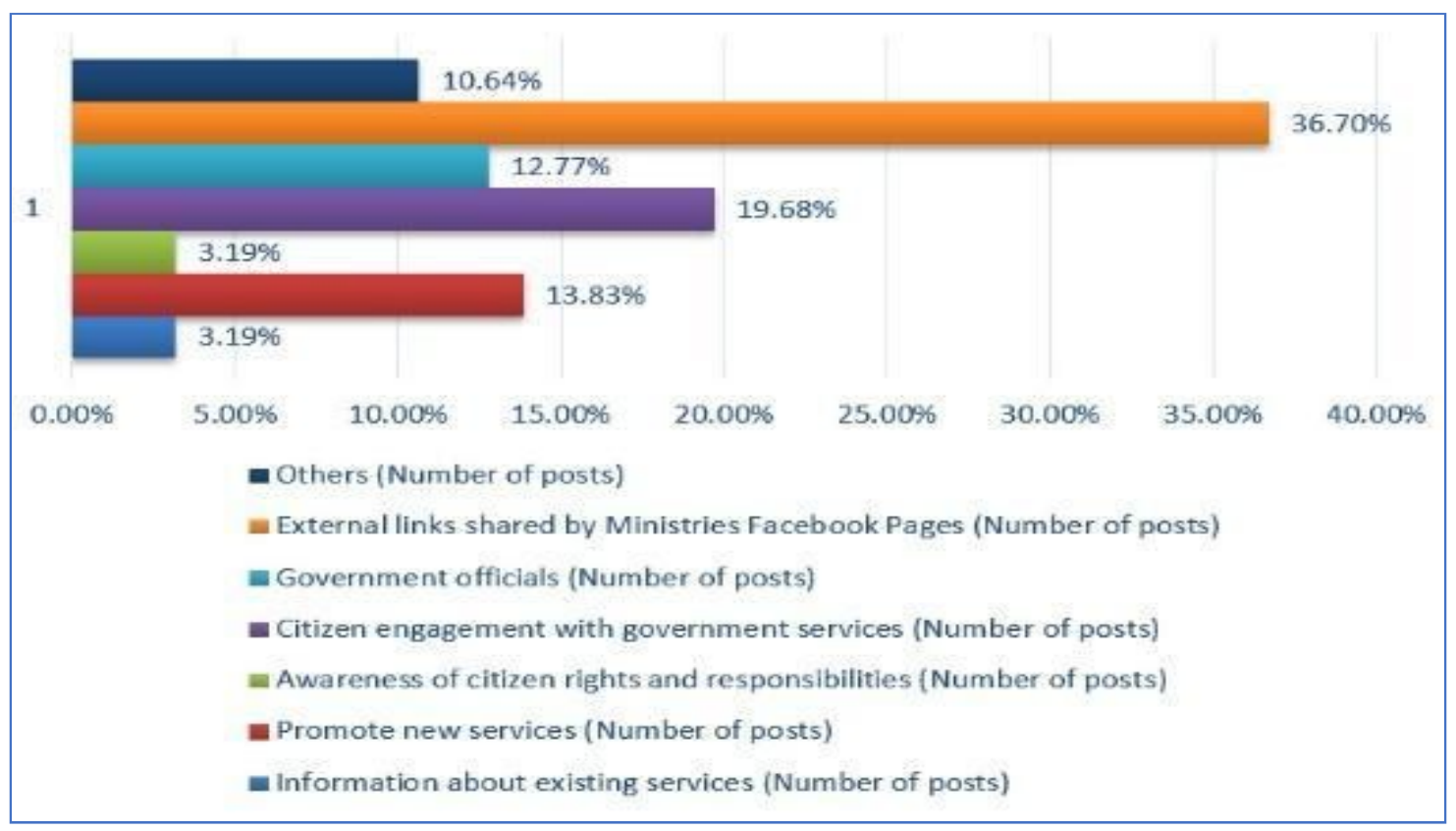

Figure: 6 Content of wall posts of Information and Communication Technology Division, Ministry of Posts Telecommunications and Information Technology

Figure 7 demonstrates that Road Transport and Highways Division Facebook Page emphasized on categories such as promote new services $33.33 \%$ as well as external links shared by Ministries Facebook Pages 31\%.

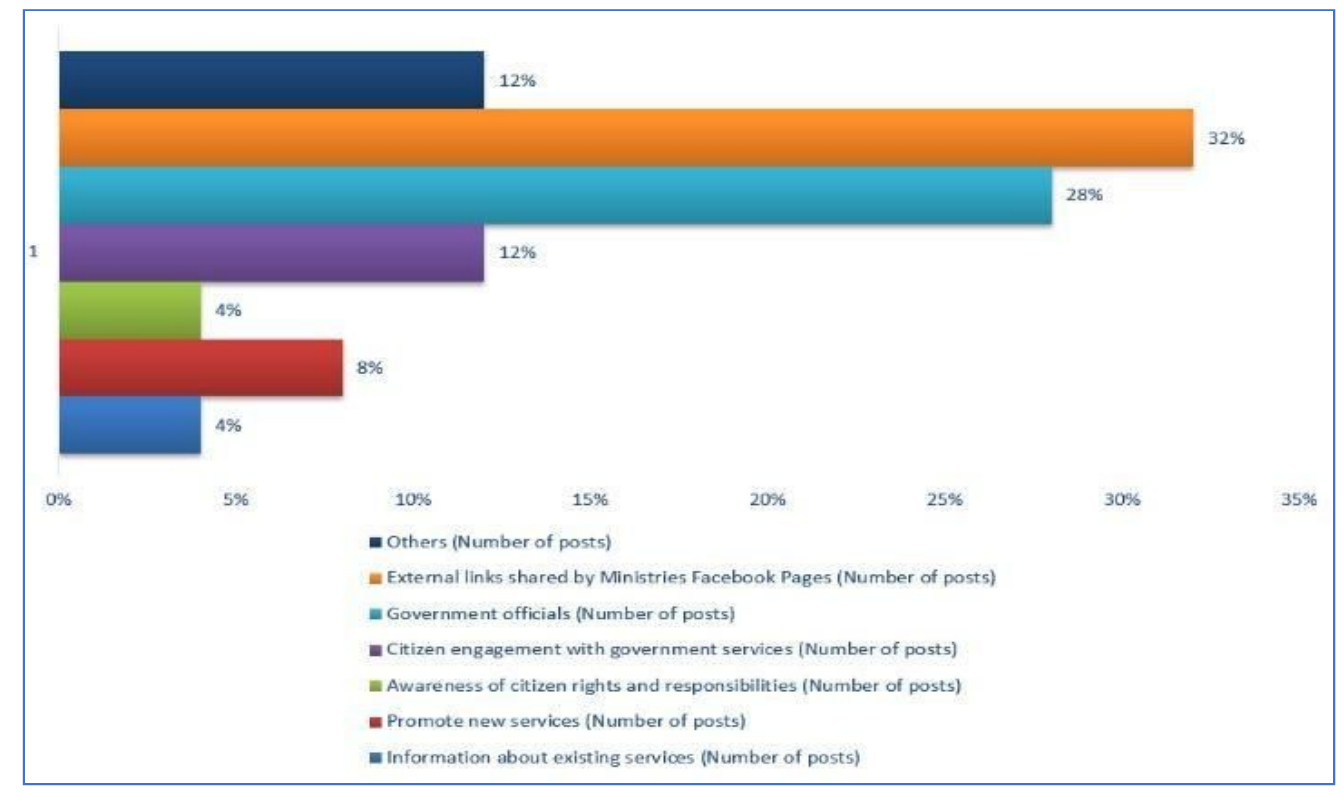




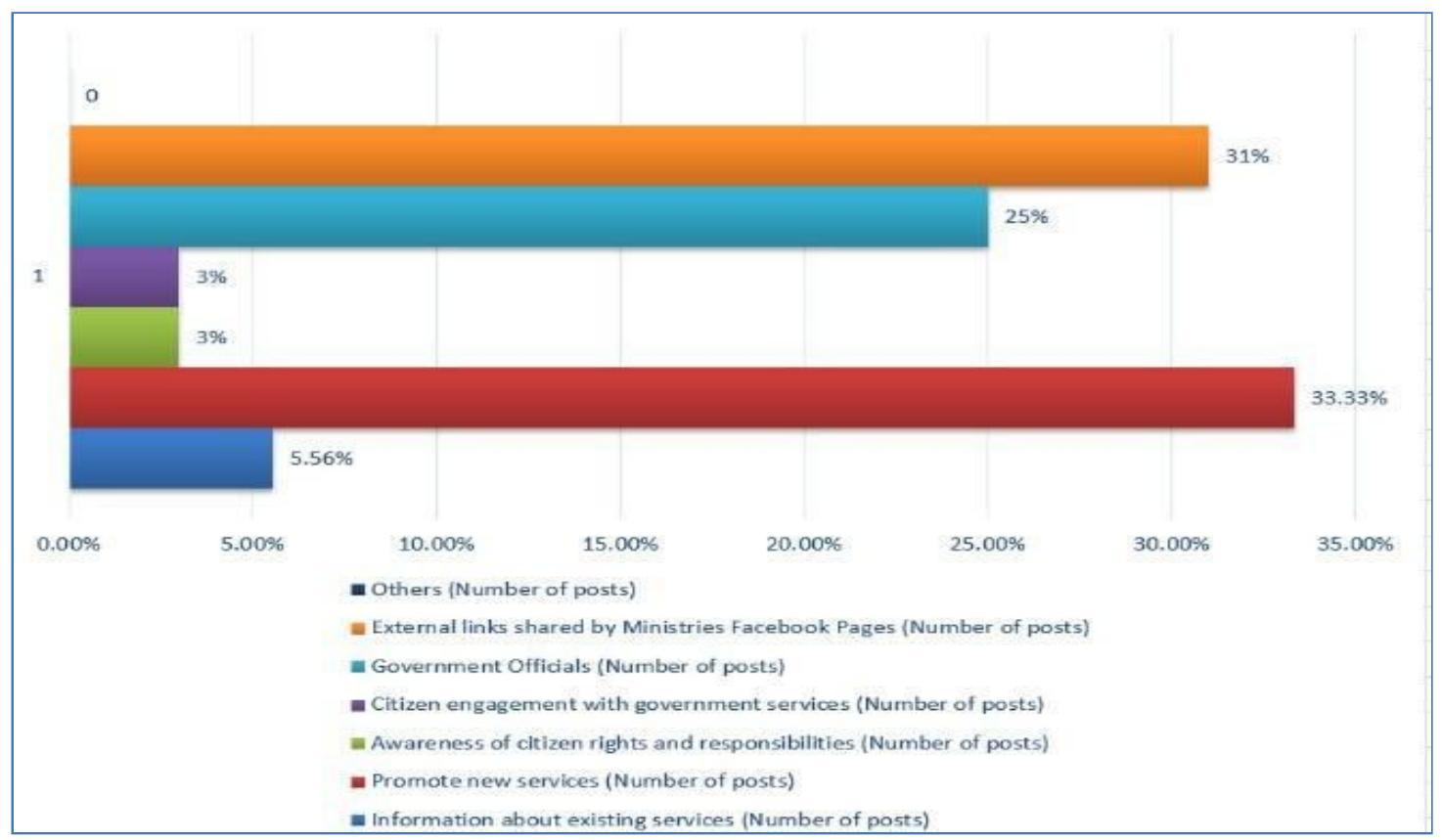

Figure: 7 Content of wall posts of Road Transport and Highways Division Facebook Page (In Percentages)

The Ministry of Civil Aviation and Tourism, Bangladesh Facebook Page have posted external links shared by Ministries Facebook Pages which percentage is $32 \%$ and $28 \%$ posts on Government officials.

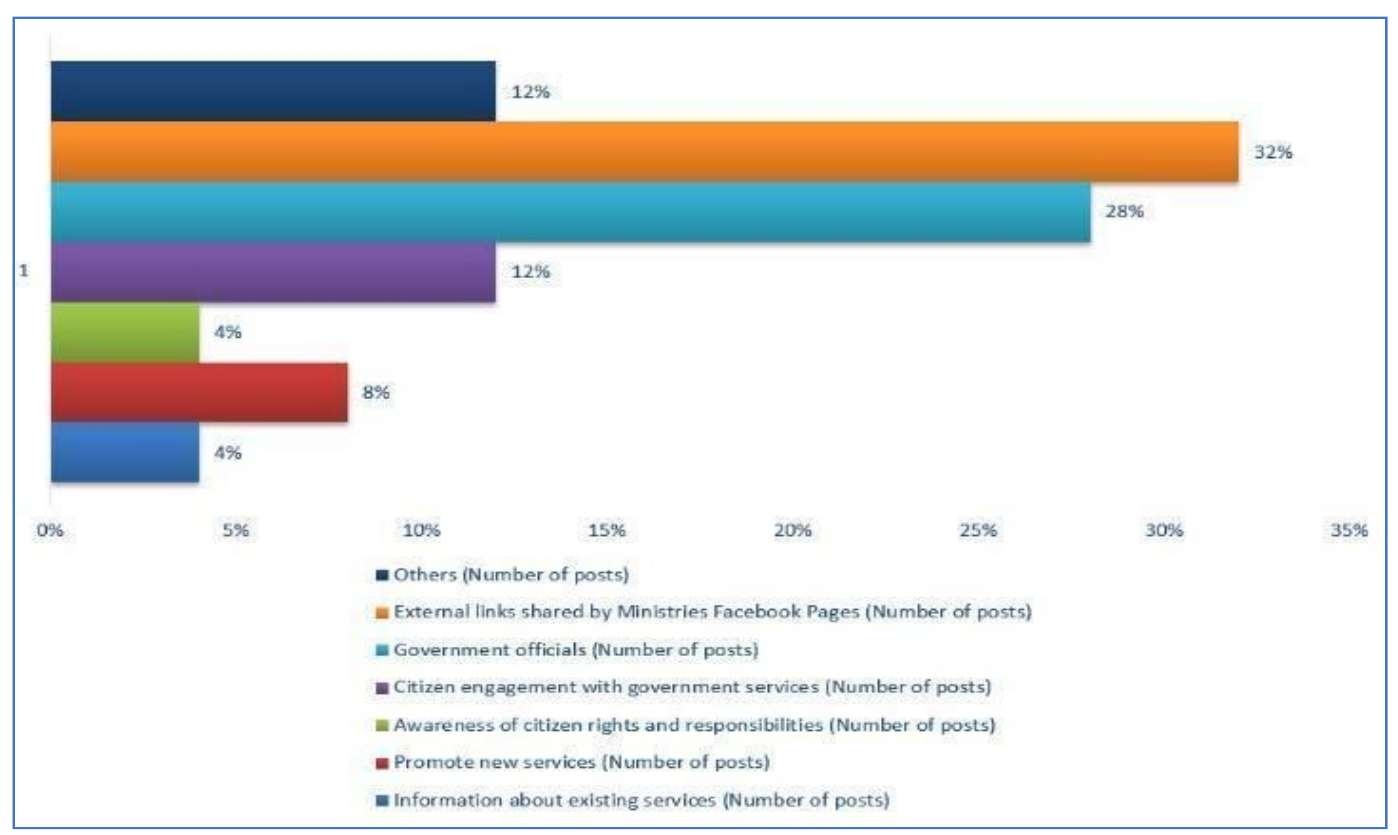

Figure: 8 Content of wall posts of Ministry of Civil Aviation and Tourism, Bangladesh Facebook Page (In Percentages) 


\section{Discussion and Implication:}

In relation to the research questions, we categorized and analyzed the types of information that the selected ministries disseminate through its Facebook page. The results show that three ministries Facebook page prefers to share external links compare to other categories whereas only one ministries Facebook page (Road Transport and Highways Division Facebook Page) spreads information on the promotion of newly services which is very essential for citizens to avail newly services offered by ministry. This indicates that other ministries Facebook pages are not able to fully utilize the Facebook page's ability regarding stimulating on the awareness of citizen rights and empowerment. Al-Aufi et al. (2017) support with the recent Arab Social Media Report that government are unable to take full advantage of social media as well as to engage citizens to design and deliver more efficient and collaborative services. Same situations have been occurring in this study.

Mickoleit (2014) suggests that through social media, government can use new sources of information to understand people's need and behaviours. He also stated that social media can help to obtain insights for better quality of services across all policy areas.

Bellstrom et al. (2016) state three suggestions for local government's Facebook usage which includes openness for user posts (positive feedback and complaints); organizations need to be prepared to handle a large number of customer services and for developing user engagement, government institutions have focus on not only one-way push tactics but also but also two-way pull and co-design tactics. Beside this, forming policies of using social media by government institutions can be ameliorated for the sustainability of using any kinds of social media. In this case, the following tactics can be helpful for the sustainability of these Facebook pages,

- Require ample time, teamwork as well as promise from government officials to maintain their Facebook pages

- Posting strategies is an effective way for the sustainability and usefulness of Ministries' Facebook Pages

- Avoid posting political issues and focus on useful content related to the ministries activities and responsibilities

- Need to arrange training program for those government officers who are handling their Facebook pages about communication skills with community, content creation, copyright infringement, how to adapt emergent strategy, be modest in tackling criticism, etc.

- Roengtam et al. (2017) point out that "online culture model via social media is needed within government organization for changes in leadership, policy and governance" (p. 362 ), so this is high time for the government ministries to use Facebook page for the upgrading the policy along with citizen engagement

\section{Epilogue:}


The citizens are directly involved with the development of a country. Bangladesh is not its exception. The present development and success of Bangladesh is the result of combined efforts of the government and public. The interaction and engagement of public with the government can be increased by opening the window of government information to public. This will surely affect the efficiency of the government, ensure transparency and as well as will engage citizen in a true manner for nation-building. Government can't do anything unless the general public actively participate in the development activities whether directly and indirectly. In this regard, Facebook can play a great role to engage people and can seek their opinion, suggestions, constructive criticism, and fresh ideas in various development projects.

Future Work: Based on the findings of this study, it will be worth investigating how Bangladesh government ministries are using other social networking sites like Twitter, Instagram, YouTube and so on. Another area of which needs further consideration is use and perception of citizens on Facebook and other social networking sites demonstrated by government different ministries.

\section{References:}

Alexa. 2018. Top Sites in Bangladesh. Retrieved March 16, 2018 from https://www.alexa.com/topsites/countries/B

Al-Aufi, A., Al-Harthi, I., AlHinai, Y., Al-Salti, Z. and Al-Badi, A. (2017). Citizens' perceptions of government's participatory use of social media. Transforming Government: People, Process and Policy, 11(2), 174-194. https://doi.org/10.1108/TG-09-2016-0056

Azad, A., Hoque, S., Mahmud, M., Mahiuddin, K., \& Kamal, M. (2017). Use of Social Media in Government for Improving Service Delivery and Government-Citizen Interaction: The Case of Bangladesh. Dhaka: a2i - Access to Information.

Bellström, P., Magnusson, M., Pettersson, J. and Thorén, C. (2016). Facebook usage in a local government. Transforming Government: People, Process and Policy, 10(4), 548-567.

https://doi.org/10.1108/TG-12-2015-0061

Bertot, J. C., Jaeger, P. T., \& Grimes, J. M. (2012). Promoting transparency and accountability through ICTs, social media, and collaborative e-government. Transforming Government, 6(1), 78-91.

Bonsón, E., Royo, S., \& Ratkai, M. (2015). Citizens' engagement on local governments' Facebook sites. An empirical analysis: The impact of different media and content types in Western Europe. Government Information Quarterly, 32(1), 52-62. doi:10.1016/j.giq.2014.11.001

Cabinet of Bangladesh. (2018). Retrieved 1 January 2018, from https://en.wikipedia.org/wiki/Cabinet_of_Bangladesh 
Duggan, M., \& Smith, A. (2016). Social media and Americans' political engagement. Retrieved 28 March 2018, from https://www.pewinternet.org/2016/10/25/political-engagement-and-social-media/

Islam, N., Mohammad Nurul Kabir, G., Md. Saifuzzaman, G., Mahmud, M., \& Rahman Khan, M. Visualizing social movements through social media. Retrieved 20 March 2018, from https://a2i.gov.bd/publication/visualizing-social-movements-through-social-media/

Linders, D. (2012), From e-government to we-government: Defining a typology for citizen coproduction in the age of social media. Government Information Quarterly, 29(4), 446-454.

Schreier, M. (2012). Qualitative Content Analysis in Practice. Los Angeles, CA: Sage Publications.

Mergel, I. (2013). A framework for interpreting social media interactions in the public sector.

Government Information Quarterly, 30(4), 327-334.

Mickoleit, Arthur. 2014. Social media use by Governments: A policy primer to discuss trends, identify policy opportunities and guide decision makers. OECD Working Papers on Public Governance, No. 26, Paris: OECD Publishing. https://doi.org/10.1787/5jxrcmghmk0s-en.

O’Reilly, T. (2010). Government as a platform. Lathorp, D. and Ruma, L, Open

Government, available at: http://chimera.labs.oreilly.com/books/1234000000774/ch02.html

Sataporn Roengtam, Achmad Nurmandi, David N. Almarez, Anwar Kholid, (2017) "Does social media transform city government? A case study of three ASEAN cities: Bandung, Indonesia, Iligan, Philippines and Pukhet, Thailand", Transforming Government: People, Process and Policy, Vol. 11 Issue: 3, pp.343-376, https://doi.org/10.1108/TG-10-2016-0071

We Are Social. 2018. Global digital report 2018. Retrieved March 2, 2018 from https://digitalreport.wearesocial.com/ 